\title{
Race and genetics in the doctor's office
}

$\mathrm{I}$ f you were tasked with expanding the holy triumvirate of touchy discussion topics - sex, religion and politics - the subject of race would be a good candidate. In the offices of family physicians, particularly in the United States, race is already a topic of interest (much more common, one imagines, than religion or politics), though attitudes differ among doctors about how much consideration should be given to a patient's ethnicity when weighing treatment options.

"Black and white physicians use race in clinical care and see it as important," says Vence Bonham, an associate investigator with the Social and Behavioral Research Branch of the National Human Genome Research Institute in Bethesda, Maryland. "Physicians use race for different reasons. Some use it to create genetic groups and to help them think about genetic variation within their patient population. Some use it to better understand the cultural background and the social experiences of their patients."

It is well known that certain diseases are more prevalent in particular ethnic groups - sickle cell disease within the black population, cystic fibrosis in those with ancestral ties to Northern Europe, Tay-Sachs disease in the Ashkenazi Jewish population. Yet many experts in medical genetics warn against basing medical decisions on race, claiming it can be a poor surrogate for genetic variation (www.cmaj.ca/lookup/doi/10 .1503/cmaj.109-4133). Creating drugs for specific races — such as the heart disease medicine isosorbide dinitrate/ hydralazine, approved by the FDA in 2005 for use by only black people may also lead to problems.

"There will be circumstances, if you target drugs to a single ethnic or racial background, when people may not selfidentify with that background and will not benefit from the drug," says Bonham. "We are learning that it is both your genome and your environment that has an influence on your health. That includes things like diet, toxins and stress. Disease prevalence differences are not all based on genetic variance. They are also based on access to care and the environmental context."

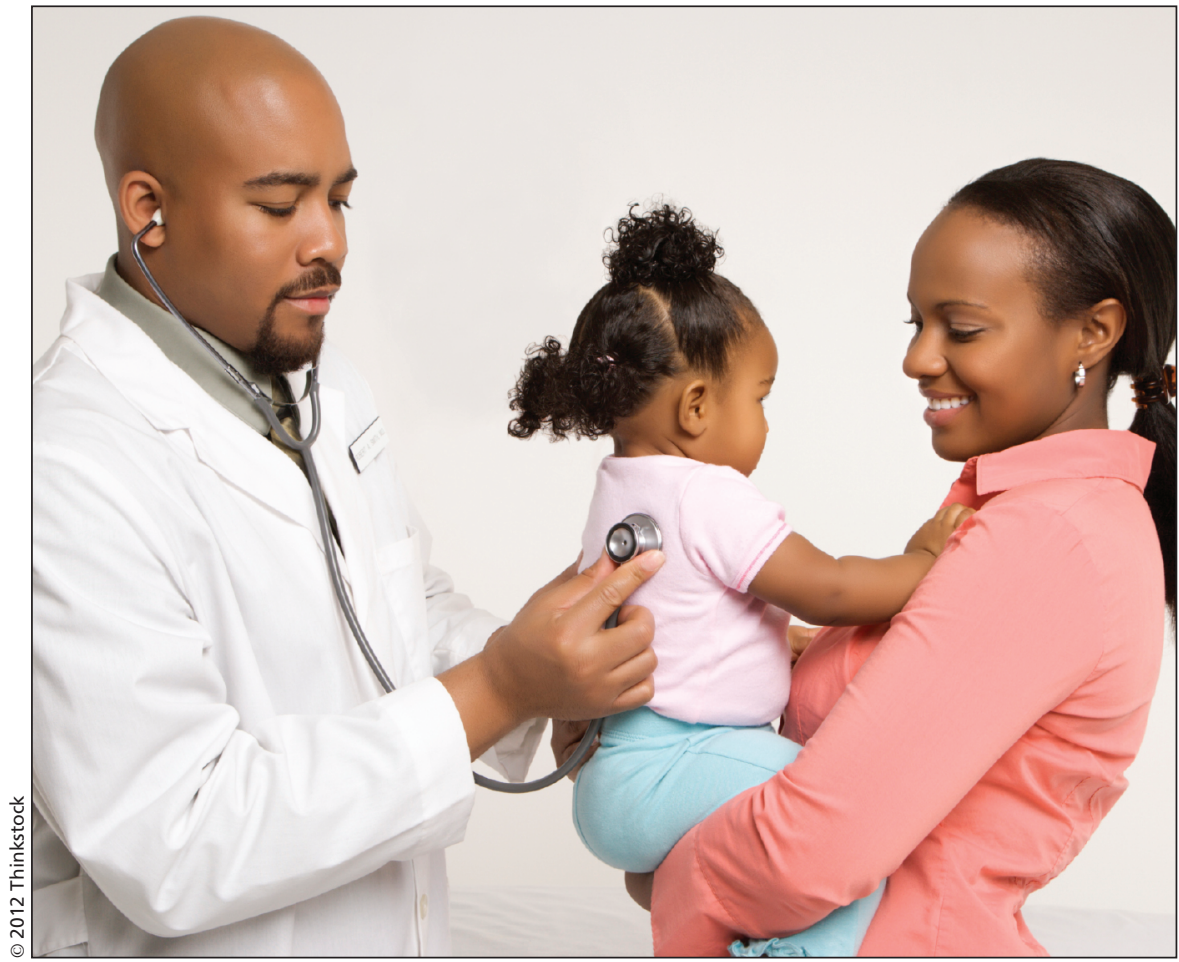

Surveys indicate that black doctors consider race a more important factor in choosing treatment options than white physicians.

But what are the attitudes of family doctors, who may have little training in genetics, about the role of race in their practices? Well, there are few people better equipped to answer that question than Bonham, who has conducted several studies on that very topic.

One of those papers, a survey of 1035 family physicians, found that general practitioners attribute race and gender differences in health outcomes equally to genetics and environment (Community Genet 2008;11:352-8). Another found that both black and white primary care physicians believe race is medically relevant but didn't agree upon why it was important (Genet Med 2009;11:279-86). More recently, Bonham found that black doctors consider race a more important factor in choosing treatment options than white physicians (BMC Health Serv Res 2011;11:183).

The attitudes of primary care physicians about race and genetics are important, says Bonham, because opinions and biases can affect quality of care and may lead to harm for patients. "Someone may come into your office with symptoms of a sickle cell disease episode or crisis but they happen to be Caucasian, and because of their racial background, that is not considered a possibility," he adds. "A bias has been established. They are white, so they can't have it. That is not scientifically correct."

Fortunately, as the price of sequencing genomes, and the use of race as a crude proxy for genetic ancestry, declines, the problems associated with treating patients according to skin colour will decrease, Bonham says.

"One, with respect to medical treatments and therapies, we will be moving beyond race and looking at individual genomes. Two, race and ethnicity will continue to play an important role in medicine, and those who are interested in addressing disparities will work to ensure that all populations benefit from genetic medicine," he adds. "Three, it's not all about the genome. It's about the roles genes and the environment play in our understanding of disease."

Indeed, the future of how race is used in medicine looks brighter. There was a time, after all, when racism pervaded many professions, and medicine was no exception, notes Althea Grant, an expert 
on sickle cell disease and chief of the Epidemiology and Surveillance Branch, Division of Blood Disorders, National Center on Birth Defects and Developmental Disabilities, at the US Centers for Disease Control and Prevention.

Grant recalls the story of a white colleague who, many years ago, was diagnosed with sickle cell disease. "The doctor decided not to tell the family. He was afraid that it would disrupt the family because it was associated with being black," she says, noting that many early writings on sickle cell disease reflected a similar attitude. "That's the history. We can't really run away from it." - Roger Collier, CMAJ
Editor's note: Fifth of a multipart series on genetic testing.

Part 1: Separating hype from reality in the era of the affordable genome (www.cmaj.ca/lookup/doi/10.1503/cmaj .109-4143).

Part 2: Popping the genetics bubble (www.cmaj.ca/lookup/doi/10.1503/cmaj .109-4142).

Part 3: Who should hold the keys to your DNA? (www.cmaj.ca/lookup /doi/10.1503/cmaj.109-4141).

Part 4: A race-based detour to personalized medicine (www.cmaj.ca /lookup/doi/10.1503/cmaj.109-4133).

\section{More News online}

A race-based detour to personalized medicine: Some medical experts claim race-based medicine is a step toward personalized medical care, but others believe it is unwise to push the field of medical genetics into the heated realm of racial politics (www.cmaj.ca/lookup/doi/10.1503/cmaj.109-4133). — Roger Collier, CMAJ

Touch the screen now to see a doctor: Interactive self-registration kiosks are being touted as the next wave in efficiency in health facilities. (www.cmaj.ca /lookup/doi/10.1503/cmaj.109-4123). — Jordan Fallis, Ottawa, Ont.

Africa's road to blood ruin: Blood transfusion programs in African nations are rife with deficiencies. (www.cmaj.ca/lookup/doi/10.1503/cmaj.109-4122). - Bernard Appiah, College Station, Tex.

CIHR doubles support for clinical research: The Canadian government will invest $\$ 150$ million in a collaborative research program with drug companies (www.cmaj.ca/lookup/doi/10.1503/cmaj.109-4161). — Lauren Vogel, CMAJ

Oxycodone class action lawsuit filed: (www.cmaj.ca/lookup/doi/10.1503 /cmaj.109-4158). — Paul Christopher Webster, Toronto, Ont.

Age, sex, location ... sperm count?: A burgeoning online network of willing sperm donors and would-be mothers are bypassing licensed sperm banks (www.cmaj.ca/lookup/doi/10.1503/cmaj.109-4156). — Lauren Vogel, CMAJ

Status quo wait times: Improvements to wait times for priority procedures have levelled off across Canada as some provinces have failed to maintain previous gains, according to the Canadian Institute for Health Information. (www.cmaj.ca/lookup/doi/10.1503/cmaj.109-4163). — Lauren Vogel, CMAJ

CMAJ 2012. DOI:10.1503/cmaj.109-4166 